$\begin{array}{cl}\begin{array}{cl}\text { Revue } \\ \text { de Ihistoire }\end{array} & \text { Revue de l'histoire des religions } \\ \text { des religions } & 4 \mid 2010 \\ & \text { Qu'est-ce qu'un « paysage religieux »? }\end{array}$

\title{
Spatially Determined Behaviors and Religious Representations : the Srubna Culture Model (Southern Russia)
}

Comportements déterminés par l'espace et représentations religieuses : le modèle de la culture Sroubna (Russie méridionale)

\section{Vadim Mikhailin}

\section{OpenEdition}

Journals

\section{Electronic version}

URL: http://journals.openedition.org/rhr/7665

DOI: $10.4000 /$ rhr.7665

ISSN: 2105-2573

\section{Publisher}

Armand Colin

\section{Printed version}

Date of publication: 1 December 2010

Number of pages: $497-517$

ISBN: 978-2200-92658-8

ISSN: 0035-1423

\section{Electronic reference}

Vadim Mikhailin, « Spatially Determined Behaviors and Religious Representations : the Srubna Culture Model(Southern Russia) », Revue de I'histoire des religions [Online], 4 | 2010, Online since 01 December 2013, connection on 19 April 2019. URL : http://journals.openedition.org/rhr/7665; DOI : 10.4000/ rhr.7665 


\section{Spatially Determined Behaviors and Religious Representations : the Srubna Culture Model (Southern Russia)}

Archaeological remnants of the "Srubnaya" or "Srubnik" culture, characteristic of the steppe regions of Southern Russia in the Late Bronze period $\left(17^{\text {th }}-12^{\text {th }}\right.$ centuries BC), offer a model of human behavior that was strictly dependent on culturally marked territories. Applied to later Indo-European cultures, this model can be helpful for deciphering certain practices and cultural codes, including religious ones.

\section{Comportements déterminés par l'espace et représentations} religieuses : le modèle de la culture Sroubna (Russie méridionale)

Les vestiges archéologiques de la culture « Sroubnaya » ou «Sroubnik 》, caractéristique des steppes de la Russie du Sud et datant du Bronze ancien (XVII $-X I I^{e}$ siècles av. J.-C.), font apparaître un modèle de comportement humain lié à des territoires culturellement marqués. Ce modèle, appliqué aux cultures indo-européennes récentes, peut servir à interpréter des pratiques et des codes culturels, y compris les codes religieux. 


\section{GENERAL PREMISES: COGNITIVE AND ANTHROPOLOGICAL}

According to some specialists in cognitive psychology, like Pascal Boyer, ${ }^{1}$ our minds are set up to develop religion, because we are highly adapted to attributing intentions to other people-we are a social species. This helps us predict what others are going to do, but inclines us to attribute intentions to inanimate things, such as rivers or trees, or regard chance events as intentional and assume that some conscious and personified will is standing behind, say, the sudden changes of our own behaviour and the behaviour of the people we know.

From my own point of view, human behaviour is highly dependent on the culturally marked territory where an individual or a group finds itself at a given moment. The less diversified and urbanized the culture is, the more this dependence is to be seen as a single structure. So, one of the best ways to perceive the possible semantics of religious phenomena is to try and see them through the "volition of spaces:" gods becoming thus-to an extent, at least initially-kind of personified emanations of the whole sets of things, organized as culturally marked spatial zones modifying human behaviour, and represented through the systems of culture codes. The "intentions" of the zones are naturally combined with the socially significant modes of human activity within their limits, thus creating grounds for the "divine sanction" for each form of activity, regulating the things done, said, perceived, remembered and transmitted as being "appropriate"-or "out of place."

To better understand developed, diverse and ambiguous religious phenomena like those we encounter in ancient Greek culture, we can first attempt to reconstruct earlier, simpler prototypes. The limitations of social reconstruction as a method are quite obvious, but if social reconstruction is inevitable when the archaeological material is structured according to some semantic patterns, based upon our knowledge of later traditions, then the vice versa procedure could also be productive. That is, usage of such reconstructions as mirrors, highlighting the later phenomena.

1. Pascal Boyer, Religion explained. The evolutionary origins of the religious thought, New York, 2001. 
A "simplification" that would allow us to go to the basic schemata of cultural-and religious-meanings production, could start from the statement that the patterns according to which we are attributing intentions to other people, are being structured at early phases of individual development. These are modeled in rather strictly delimited micro-group contexts, thus determining the basic (and quite different) levels of situation encoding. These primary levels of encoding (together with an individually-emotional one) later lend us their meaningful elements in the process of our adaptation to wider levels of encoding. Thus, coming to elements supposes an attempt to leave aside the public and general levels of situational encoding, coming down to main micro-group ones-those being the family, the neighbourhood and the pack. ${ }^{2}$

1) Family level. The first milieu any person is normally exposed to is the family, which in itself offers a very strong pattern of experience-structuring. As a child, one always knows which zones in the household are "under control" of this or that member of your family, which smells, activities, parts of discourse, physical qualities (etc.) are associated with each of them. The patterns and meanings concerning the relations within the family, the figures of mother, father, brother, child (etc.), the "inborn" hierarchies and the ideas of one's own rights and possibilities. The emotional states coming from comfort or discomfort in particular family situations are to be transmitted to interpretations of out-of-family situations, just following the logics of economy of the "mind job."

2) Neighbour level. There are other grown ups, different from your family and coming from outside your family circle, who interact with your family, who have no defined place in your household and are natural outsiders, but nevertheless sometimes seem to be very important to the members of your family. Inter-family contact is the "place" where a person gains his or her first experiences of "treaty" behaviour: with no inborn qualities, responsibilities and rights peculiar to this or that outsider, but with him/her having certain qualities, responsibilities and rights that other members of your family apply to him/her situationally and expect you to do

2. Vadim Mikhailin, "Na miru i smert krasna? Perekodirovajije situatsii kak kommunikativnyj (i politicheskij) resurs" ["Does misery like company? Situational re-coding as a communicative (and political) resource"], Neprikosnovennyj zapas, 1 [063] 2009, pp. 114-124. 
the same. The behaviour patterns and encoding models thus gained form a level of meanings totally different from the family one: here exist neither "inborn" family hierarchies nor presupposed semantically saturated domains attached to each person; instead, some special semantic field is created especially for the "neighbourlike" contacts, distanced from intimate family knowledge, having their own rituals and sets of rules, their own means of evaluating the possible communicative positions and tactics.

3) Pack level, generated from the exposure of a person to a milieu of outsiders of his/her own age and (usually) gender. Here $\mathrm{s} /$ he has to deal with the experience of structuring and encoding the highly agonistic hierarchy of equals, with the rules and peculiarities having nothing to do with the previous two levels of encoding. No unchanging established positions, crucial for the family and in some aspect to the neighbour levels exist here. Any position, any status is situationally determined, and an individual is prompted to permanently show off in order to gain or to retain a situational status; here ideas of luck and unluckiness are formed, ideas of destiny and fate, of gaining and losing, of being involved in highly emotional relationships of the positive as well as of the negative kind with total strangers, just because they are your peers in this or that situationally meaningful context.

So, from the point of view stated herein, the best "simple" culture that could highlight at least some aspects of more complex IE traditions, has to produce a combination of two main features. It needs 1) obvious diversification of main behaviour patterns depending on culturally marked territory, and 2) no inclination to politogenesis which would leave us face to face with the microgroup levels of encoding.

At once a further problem arises: those cultures not inclined to politogenesis tend to leave us no large-scale archaeological sites, to say nothing of the written traditions.

Given these factors, one needs to look for a culture that:

1) is statistically representative in terms of its surviving archaeology;

2) has existed continuously for a substantial period of time, allowing us to identify what is stable and representative of the longer term. This allows us to avoid dealing with patterns that result from short-lived accidental concurrences of circumstances; 
3) has left enough data to allow conclusions concerning the different situationally modified ways of behaviour peculiar to its cultural tradition.

\section{SRoubna CUlture: GeNeral DESCRIPTION}

There is a culture satisfying all these specifications, namely the Sroubnaya (Sroubna, Timber-grave) culture. It existed continuously ca. through the 17th till the 12th (or possibly even 10th) centuries BC By itself, it spans the period of the Late Bronze Age in the vast steppe, forest-steppe and desert-steppe regions at Northern Pre-Black Sea and Pre-Caspian areas of Southern Russia from Volga-Ural interfluve in the east to Dniepr in the west. It has left a great number of archaeological sites, wonderfully stereotypical for such a vast geographical dispersity. The most common form of Sroubnaya settlement was a single big family homestead, with a house big enough to shelter ten to twenty people, with a kind of kraal and some outhouses. The houses were of a half-dugout design, with the walls presumably built of thick branches (or thin timber) covered with thick layers of clay, or wattle and daub-and a not too high thatch span roof supported by (usually two) rows of props. It typically contained an open fireplace, and along one wall an earth podium served as a bed for all the inhabitants. Each house of this kind would be inhabited by several generations, presumably of one and the same family, being in use for more than a hundred years.

Distances dividing the households vary but usually are no less than five to six kilometers. The households are usually situated close to rivers and creeks, above the spring tide level. Not far from the houses but at some distance burial mounds are usually situated, apparently intended only for deceased members of the family that occupied the house. Low mounds cover the graves with the walls laid either with thin timber (hence the name of the culture, sroub being Russian for a log cabin), or with slabs of stone, thus resembling very much the usual home space the living Sroubniks were accustomed to. The burying site inventory is usually very poor, consisting of a pot and sometimes some other objects like bone buckles or bronze temporal rings, bronze knives or stone mace heads. The skeletons lie in a characteristic crouched position on 
their left sides, heads more or less to the east, legs and arms bent, hands in front of the face. A ceramic pot is usually located near the head of the deceased. There have been numerous findings of single buried skeletons within the vicinity of the houses occupied by the living, and these are supposedly victims of foundation rituals.

Two things that particularly interest me within the context of this presentation are: (1) the tendency of this culture to lack any distinct inclination to politogenesis, despite its long historical duration (no less than half a millennium) and its geographical area, archaeologically representative and presumably Indo-European, and (2) pronounced peculiarities showing different spatially bound modes of behaviour that co-exist within the limits of one and the same culture.

Unlike their eastern neighbours, predecessors and possibly relatives, in the Andronovo culture, Sroubnaya people left behind no fortified local centers like Sintashta or Arkaim. The very principle of their social organization seems to deny any grounds for wide political spaces, including more than several dozens of people. Further, this society seems to have lacked any pronounced military features. Finds of any kind of Sroubnik weapons are remarkably rare, and even among these few there are grounds to suppose that the objects had primarily either hunting (arrowheads) or ritualistic (mace heads) functions.

Sroubniks also appear to have been very "ecologicaly-minded," as we might say nowadays. Their use of wood (not very abundant in South Russian steppes flood-plain forests), reveals the very pragmatic and environmentally responsible practice of coppicingcutting common lowland trees like alder or willow about 1 or $1.5 \mathrm{~m}$ above the spring tide level. In just a few years the cut tree grows from the "cop" right to its previous proportions, ready to give another crop of thick branches, which the Sroubniks used for construction, handicrafts, and firewood. Pasturing practices also seem to have been of a partial load mode, using the resources of one's own land very sparingly-at least at their core territories.

Here we come to the most interesting peculiarity of this culture; it existed at one and the same time in two registers, being both settled and nomadic. Every autumn, part of the Sroubnik population traveled long distances (up to $700 \mathrm{~km}$ ) to the south, where there was better winter pasturing, and the animals could dig up the standing 
dry grass from under snow, which is much thinner there than at the core Sroubnik territories. On the southern pastures we find the so-called "dune encampments." The burial sites left there indicate that the "camps" were used for the seasonal stay of groups of 20 to 30 people, mainly young males. The burial ritual is the same as in the core territory-the differences being mainly the shallowness of the graves, the lack of overhead covers (making no roof for a dead man in this foreign land), the absence of some ritual peculiarities (e.g. no chalk or raddle sprinkling on the corpse), and the chance character of the burial sites themselves-the majority of graves are inlets into the mounds of the older Yama culture. The southern land was definitely looked upon as alien, so there was no reason for burying winter casualties according to home rules. This change in the perception of the land points to another, very characteristic peculiarity of the Sroubnik winter shepherds at their southern pasturing grounds; in total contrast with their "home" habits, their winter pasturing was absolutely un-sparing. Pedologists studying the genesis of the North-Pre-Caspian deserts, state that they began as the result of the predatory pasturing that began there some 4,000 years ago. ${ }^{3}$

The social habits indicated by these data are very interesting. If the seasonal shepherds' bands consisted of 20 to 30 young men, then they were to come from 7-10 households, every household being able to produce no more than 2-4 teenagers or young men at any given moment. This gives us two absolutely different (seasonally and territorially determined) models, not only of resources management but also of social organization. The rigid paternalist model that was basic to the loose agglomeration of independent households, deep-rooted in their own land and ancestral graves, produced for a period of 5 to 6 months of each year another model, which, in its own turn, appears close to the model of an archaic Indo-European Maennerbund, as perceived in the European tradition since Stig Wikander.

The very necessity of "changing mentality" every 6 months calls for a detailed analysis from the point of view of the possible impact it had on the cognitive aspects of Sroubnaya culture-at the individual as well as group levels. Being born into the closed milieu

3. A. G. Doskatch, Prirodnoje rajonirovanije Prikaspijskoj pustyni [Natural geographical demarcation of the North Pre-Caspian semidesert], Moscow, 1979. 
of a Sroubnaya household implied rather specific characteristics peculiar to the formation of the family level of situational encoding, determined by those very conditions the family existed in. Close and constant bodily contact with all the members of the family (they all used to share one and the same earthern bed) couldn't but develop a strong sense of belonging to the family group-the living as well as the dead, "sleeping" not far from the house. The close association between the living and the dead members of the family was surely intensified by the fact that both categories slept underground: strengthening in addition the feeling of "belonging" to this very patch of local landscape. Thus the resources produced on one's own land could feel inalienable. It's hard to imagine anything like cattle-lifting or other theft among the neighbouring Sroubnik households. The almost total absence of weapons at Sroubnik sites reinforces this view. At least some of the occasions usually seen as social, in the majority of known cultures, seem to have been totally private among the Sroubnaya people. Burial for instance (at the core territory), offered very few traits that could be perceived as meaningful outside the family milieu.

Even so, regular contact between households was necessary. Leaving aside the traces of handicraft production (remains of household foundries and tanneries) that imply the existence of local trade at least, the regular seasonal (autumn and spring) passage of large flocks through land populated by families that were sensitive to the integrity of their pasturing resources and, moreover, to any kind of border violations, must have necessitated a whole network of local diplomacy. Flocks being driven by teams of youngsters from various households must have made this diplomacy the more necessary. These contacts were necessarily timed to seasonal occasions and exercised mainly through those people embodying the families' control over the respective territories; one could hardly doubt that these functions had to be exercised by pater familias. Apart from droving, two other major, seasonal social events were likely: marriages and hunting. The first, implying a procedure close to Roman emancipatio and, in some aspects, also to ver sacrum, would include the expulsion of the newlywed couple, together with some other dependants, from the lands of both families. Sroubnaya households could survive in given conditions if (1) only one set of adults (one male and a limited number of females) was 
procreating within the limits of one "estate," and (2) if no less than 5-7 able-bodied men and women populated each. So the formation of a new household had to imply not only the search for a suitable land lot, but also the formation of a new "tribe" with its own ancestral rights to the newly acquired land (killing one of its members and burying the body close to the house seemes to be perceived as the formal beginning of the line)-losing at the same time the close connection with the previous ancestral traditions or preserving them in some indirect forms. The most probable pattern of such a family cell could be imagined as one grown man, the new pater familias, together with some fertile women and a handful of adolescents and children, one of their number destined to be sacrificed and to become the first in the new line of ancestors, and the others-to leave the new estate half a year later to drive their flock to the south.

Such partitions necessarily took place in spring, after the "boys" returned from their winter pasturing. This is because a new family could not survive if it was formed right before the cold season, and to survive, it had to have enough cattle. Keeping in mind the usual inalienability of Sroubnik estate resources, one must suppose (1) the time of transition (April/May or October/November) as making such a transaction easier, and (2) the necessity for a man going to marry to have a flock of his own. The latter supplements the Sroubniks winter marginal practices-apart from the predatory pasturing-with no less predatory cattle-raiding habits, facilitated by the very nature of their bands there and also by seasonal factors like freezing of the rivers, which makes the steppe open and penetrable in any direction (the autumn and spring migrations are done along the rivers). Remember, that peoples from the Eurasia steppe regions (like Sarmatians, Uzbeks or Mongols) still kept the habit of winter raiding in "historical" times.

Here we come to the gender-oriented aspects of our social reconstruction. The Sroubnik estates were well suited to supply one big family, even though rather strict regulations had to be developed in everything concerning the procreation policy. The females suitable for coupling could only be obtained from other households where they were most probably engaged in agriculture, which meant that they constantly stayed in the proximity of the house and had no opportunity to meet or even to see the boys from other families. Moreover, there are some reasons to suppose that 
even during the summer season boys of the "pasturing" age didn't sleep in the house, and thus did not share the bed with their female relatives. The fire remainders in the direct vicinity of the houses are indications of someone sleeping outside in the summer. So possibly after coming of age, the boys were segregated from the rest of the family, spending the summers at the family territory but outside the house, and the winters-at southern steppes. So the only opportunity for them to see girls from other families was during the autumn or spring droving of cattle through other families' lands. Other tactics imaginable could have included friendship (or other band-produced relations) with boys from other families, who had sisters.

Hunting is another seasonal, social event, the most productive form-before mastering horse riding-being collective chases using beaters and nets. The use of hunting nets is attested by massive stone net loads, sometimes at sites where no fish bones are found. Hunting semantics, that have survived in Ossetian epics, clearly divide hunters into two categories: those who chase prey and have no share in the catch, and those who ambush prey in "narrow places," who did have shares-the age and status characteristics of the hunters correlating to their warrior statuses. The net as a marker of "holding" might be the prototype of the most characteristic Sroubnik pottery ornament (Fig. 1). The practice of using the teenagers as beaters, that exists till now, say, in England, allows the autumn chases to be regarded as local opportunities which, apart from strictly food-producing purposes, were used for probing the young men bands before their winter expeditions. The practice of using nets for water fowl hunting (together with chasing) that still exists in Russia offers one more parallel. The young men therefore left to spend half a year at their winter southern marginal quarters at the very time of the massive water fowl migration to the south, and their return had to coincide with the birds' reverse migration. The semantics of crossing borders (including the border between life and death) connected to birds and other (composite) winged creatures, the winged supernatural beings serving as communicators between the world of living and the world of dead, can be based on situations of this kind. The settled Slavonic locus of a dying warrior asking a migratory bird (usually a cuckoo) to bring a word about his death to a personally significant female (mother, wife or bride), the habit of "taking hostage" of a migratory bird for the winter and 
setting it free in the spring, the superstition that a bird that flew into the house brings death to one of the family members may all belong in the same semantic field. Another possible zoomorphic semantic connection is to wolves, living to just the same pattern as Sroubnik boys-spending the summer with their families and having very little or no large-scale hunting activities, and forming the actively hunting aggressive packs for the winter half of the year. Wolf packs were natural counterparts for the packs of youths in the southern steppes, so the later animal-style dichotomy of wolf and dog as markers of the "ephebic" warrior status, being basically the same but in personifying respectively the aggression directed from inside out or vice versa, can be linked to this practice also. "Dogs" to their flocks, the young men could easily turn into a pack of bipedal wolves for the rival bands, coming, say, to the north PreCaspian from the regions lying so far away from each other like Middle Volga and Southern Urals.

The southern steppes were thus territories of challenge and freedom, where the "destiny of a warrior" could be tried before the possible (and desired) settling down on one's own land in the north, and-a natural melting pot, where the bands coming from different regions could meet and test their political skills, totally different from those of their fathers. These very lands seem to produce the first nomadic groups in a more or less strict sense of the term-just after the art of horse-riding was discovered, meaning that cattle raiding practices could lose their previous natural limitations. The Sroubnik culture disappears right at that period: and it is tempting to assume that no aggression from outside caused this (at least, no archaeological traces of such aggression survive). If during the previous centuries the marginal existence in the Southern steppes quite naturally combined freedom with a strong sense of deprivation and hunger (in all the possible social and physiological meanings), the newly acquired mobility (coinciding with dramatic changes in climate) allowed the "joint teams" of "younger sons" to change their life strategies no less dramatically. If earlier the acquiring of a flock of one's own, necessary to gain one's own land, family and a line of ancestors, was a long and winding road, now the warrior's luck and a good retinue could solve the problem in one season. This, in its own turn, ended the peaceful Sroubnik pastoral. It is futile in this model to try and assess the problem of ethnogenesis in 
the Late Bronze and Early Iron ages in the South Russian steppes, but even the Scythians appear to be not so strictly nomadic as they seemed to be-having the settlements situated to the north from their pasturing zones in the North Pre-Black sea regions. Therefore, the Sroubnik model might possibly shed light on the nature of some deities' images, preserved by Scythian toreutics, like two figures of goddesses: one sitting with a mirror in her left hand facing a standing young man with a rhyton (Fig. 2), and the other-a frontal image of a goddess with her hands apart, holding in them animals (or some other items), and with her tunic divided at the crotch (Fig. 3)-the one analogous to the well-known Potnia Theron figure, but frequently being birdlike-winged, feathered, having a bird's tail, etc.

\section{"SROUBNA MODEL"}

If we now attempt a model, covering the possible religious aspects of Sroubnik culture, starting from this reconstructed diversification of cultural practices according to different culturally marked territories, the two juxtaposed entities seem quite obvious. The central, nuclear zone and the summer mode of existence just have to apply to a father-like figure having the functions of control over the territory, family and any kind of resources; and a mother-like one, having the functions of birth/abundance/agricultural production. The former is to be connected to the ancestors, especially to their male part, the latter-to the female ones. The winter/marginal way of living, opposed to the family mode in all aspects (territory, social organization, way of living and dying, diet devoid of any agricultural products and also such home-made items as cheese and butter, etc.), is to be connected with figures akin to the later Greek Apollo and Hermes.

However, the social model that could be thus developed seems far from being simply bipartite, breaking up into the summer, family-based, and the winter, marginal components. Firstly, the core territory was not homogenous, including a nuclear, housing zone; a zone of pre-house agricultural and resource-accommodation practices, being at the same time the zone of the family females' residence; and an extensive pasturing and hunting zone, by all means 
perceived as "belonging" to the male members of the families. On the same model, a tripartite structure could be extended over a much wider topographical context, if the female connotations of the neighbouring estates are kept in mind. The bride-producing functions of these territories could be supplied by a possible ideological inclusion of the bands of youths crossing neighbouring territories twice a year, being at once alien and "of one's own," and by the obvious initiatory connotations of the process. In the autumn, the boys, together with the migratory birds, go to "no-man's land," wild and dangerous, where some of them will possibly die but the others could acquire the characteristics necessary for a higher male status. They drive away with them the biggest part of their families' livestock, and in the spring they return, wild and dangerous, but abundant with food resources, driving the livestock back to their families. In both cases they pass through rites of passage, dying from one mode of living and being reborn to another. So a female figure marking the border is absolutely adequate to the situation. The mirror, changing everything that is right to everything that is left and vice versa is right at its place here-if the usual semantics of right and left in the IE traditions are kept in mind, and the relevant differences in male behaviour within the "home" and "marginal" zones correspondingly, with everything that is "right" transforming to "wrong" and vice versa. The typical IE semantic controversy, uniting in one and the same root paradigm the meanings for "friend," "other," "guest," "member of a warrior band" and "enemy" seems to fit the pattern of a man able to "switch" from a beast-like state to the "human" and back (see the Scythian plaque Fig. 4). So the Scythian image of a goddess sitting and holding a mirror before a standing young man with a rhyton could reflect just this ritual pattern. "Being born anew" by this goddess is also to be seen in the Scythian toreutics (Fig. 5).

The idea of dying and being reborn seems also to be represented in another settled Scythian icon-that analogous to the Greek "Potnia Theron." The accent at the pubis of the figure, where the tunic is divided in two, and also at its breasts, together with its frontal position and holding of two beasts to her left and to her right seems to contain a representative set of meanings, if the semantics offered are kept in mind. The death connotations as well as the connotations of crossing the border could be supported with snakes as the elements 
of the symmetrical composition, as at the plaque from Kul-Oba, seen earlier or at the horse headpiece from Bolshaya Tsimbalka (Fig. 6). The practical use of the latter object is also meaningful: being located at the horse's forehead, the goddess is to symbolically "open the way" to the rider, "look for kairos," the exact point where the border can be crossed. The "flying," "bird-like" characteristics of the goddess could refer not only to swiftness as a specific characteristic of crossing between life and death, but also to the less abstract, but no less semantically rich parallels with the migratory birds (Fig. 7, Fig. 8). Even on the plaques that seem to represent genre scenes-like at the plaque from Bolshaya Bliznitsa (Fig. 9)-the set of familiar details (kalathos, accent at the breasts and pubic area with a divided tunic) might be meaningful, especially if we take into account the funerary context of the plaques. Interesting parallels to much later folklore traditions could also be seen in another, ladybird-like image of the goddess, as we see her on the plaque from the Alexandropol tumulus (Fig. 10). The nursery rhymes ("Coccinelle, demoiselle, bête à Bon Dieu") accompanying the childish ritualistic game of sending the bug to the sky, common to IE regions situated very far from each other, may have much deeper and semantically richer roots than at first appear.

\section{SOME POSSIBLE OUTCOMES}

The "initiatory" ritual semantics as a most popular key to the interpretation of the diverse data coming from archaic IE cultures, including the ancient Greek one, might be not so strictly bound to the initiatory ritual in its exact age-structure sense. On one hand, the experience of crossing the borders of "normal" life was (and still is) of a much more widespread and mundane order, than a unique experience at the brink of adolescent and early adult statuses. On the other hand, the experience thus gained and encoded at the "band" level of the individual as well as the group perception, might have a life-long impact on the ways the individual (as well as the group) would "read" the situationally significant informationeven if the situation itself bore no immediate relation to the initiationary semantics. The same might also be said about the patterns of encoding, gained at the family and neighbour levels. 
Before looking for any general and abstract ideas-like fertility or power or forces of nature-behind any religious phenomenon, one has to pose a simple question: what primary patterns derived from the most simple, micro-group contexts had to be actualized by the people of the culture we are studying-even if those more abstract and complex ideas are what we find in the texts their intellectuals produced.

vmikhailin@gmail.com 


\section{ABBREVIATIONS}

SK - Skythische Kunst. Altertümer der skythischen Welt. Mitte des 7. bis zum 3. Jahrhundert v.u.Z, Leningrad, 1986.

SNS - Véronique Schiltz, Les Scythes et les nomades des steppes. VIII siècle avant J.-C. - Ir siècle après J.-C., Paris, 1994.

\section{BIBLIOGRAPHY}

N. K. Kachalova (ed.), Pam'atniki sroubnoj kul'tury. Volgo-ural'skoje mezhdurech'je [The relics of Sroubnaya culture. Volga-Ural interfleuve], Saratov, 1993.

V. A. Lopatin, Sroubnyje poselenija stepnogo Volgo-Ural'ja [Sroubnaya settlements of the Volga-Ural steppe], Saratov, 2002. 


\section{ILLUSTRATIONS}

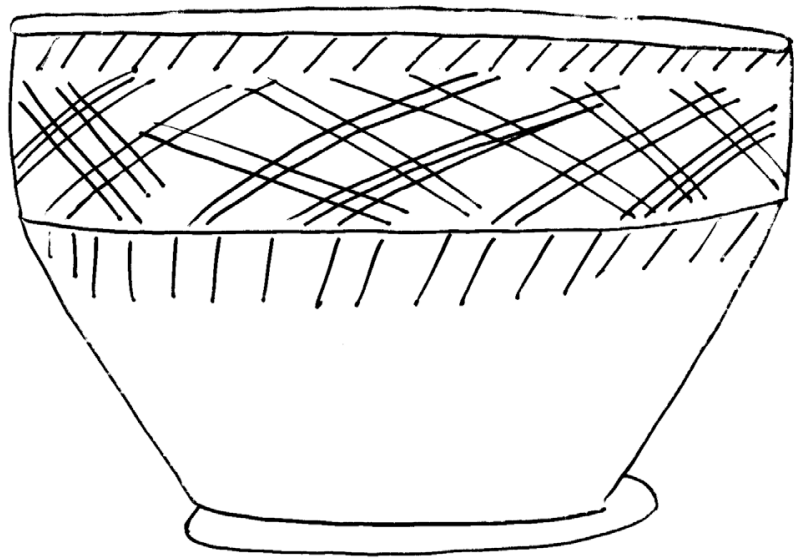

Fig. 1. Typical Srubna pot.

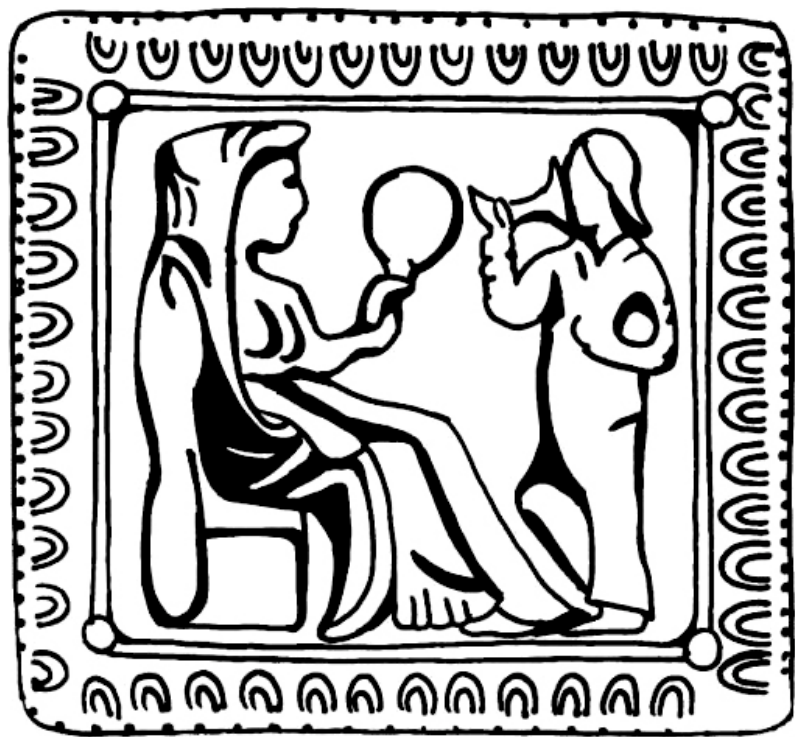

Fig. 2. Golden plaque, Koul-Oba tumulus, IV BC. St. Petersburg, Hermitage. (SNS, 137) (del. Ekaterina Reshetnikova). 


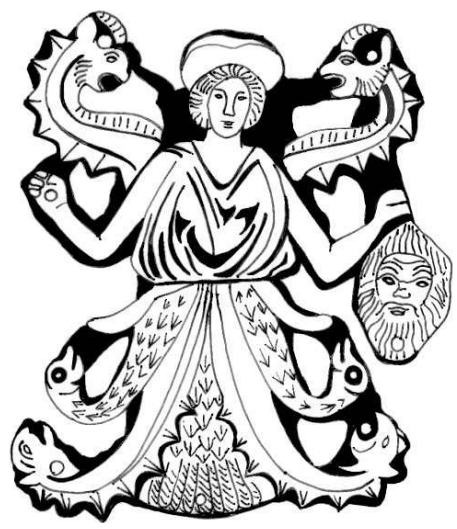

Fig. 3. Golden plaque, Koul-Oba tumulus, IV BC. St. Petersburg, Hermitage. (SK, 203) (del. Ekaterina Reshetnikova).

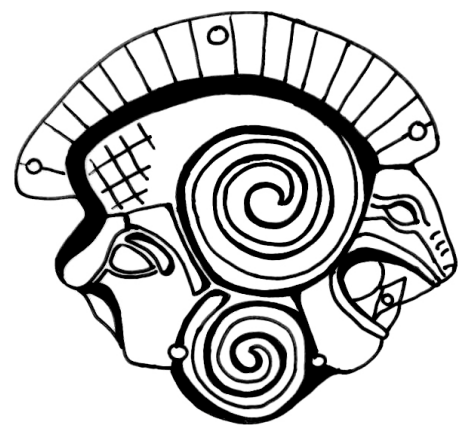

Fig. 4. Golden plaque, Semibratniy 2 tumulus, V BC. St. Petersburg, Hermitage. (SK, 85) (del. Ekaterina Reshetnikova).

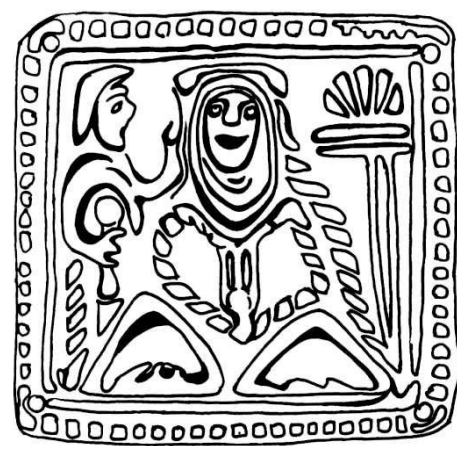

Fig. 5. Golden plaque, Koul-Oba tumulus, IV BC. St. Petersburg, Hermitage. (SK, 258) (del. Ekaterina Reshetnikova). 


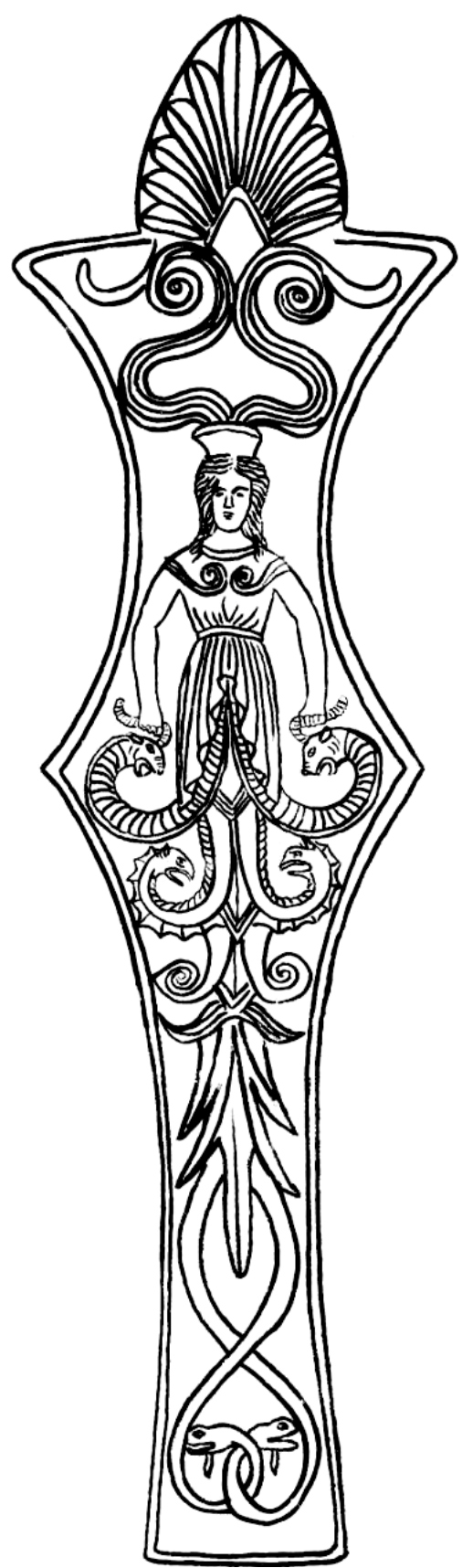

Fig. 6. Horse headpiece, Bolshaya Tsimbalka tumulus, IV BC. St. Petersburg, Hermitage. (SNS, 136) (del. Ekaterina Reshetnikova). 


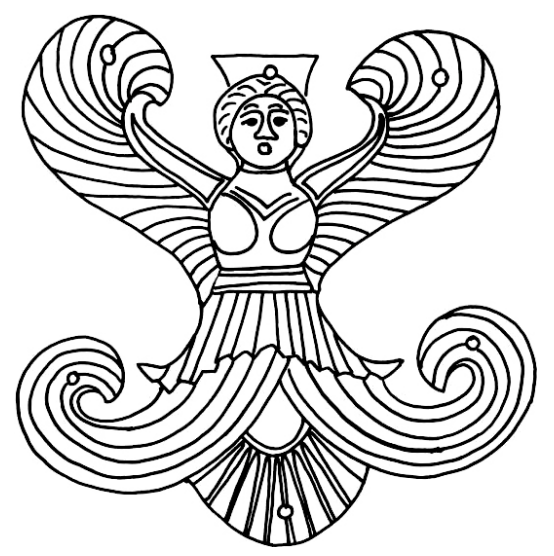

Fig. 7. Golden plaque, Koul-Oba tumulus, IV BC. St. Petersburg, Hermitage. (SK, 208) (del. Ekaterina Reshetnikova).

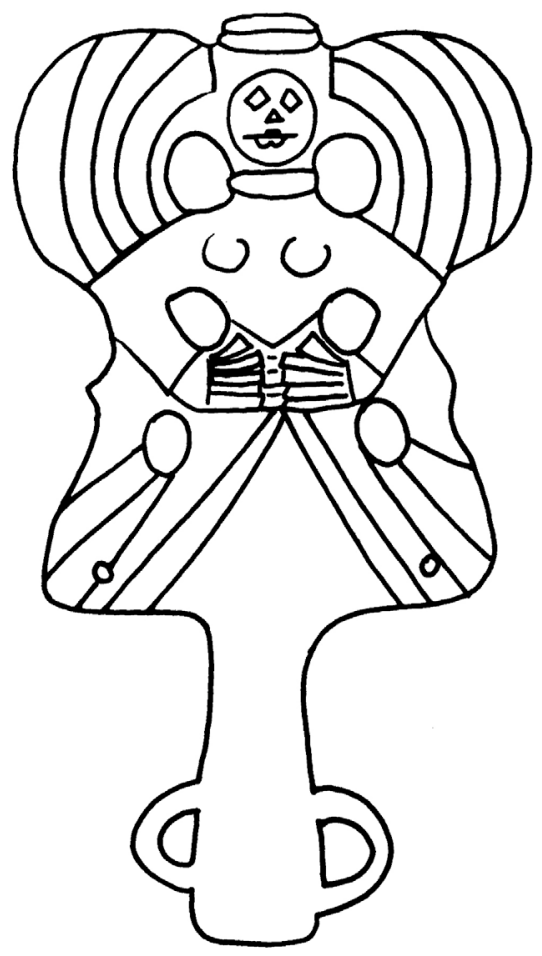

Fig. 8. Top-piece, Alexandropol tumulus, III BC. St. Petersburg, Hermitage. (SNS, 155) (del. Ekaterina Reshetnikova). 


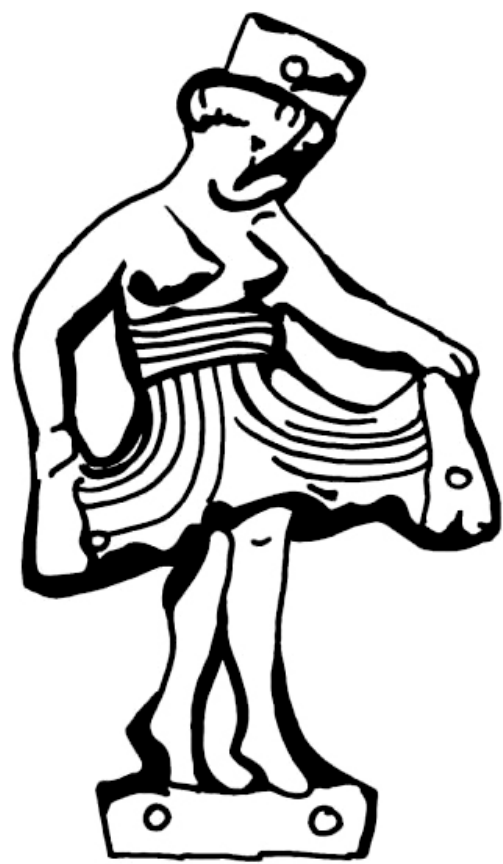

Fig. 9. Golden plaque, Bolshaya Bliznitsa tumulus, IV BC. St. Petersburg, Hermitage. (SK, 209) (del. Ekaterina Reshetnikova).

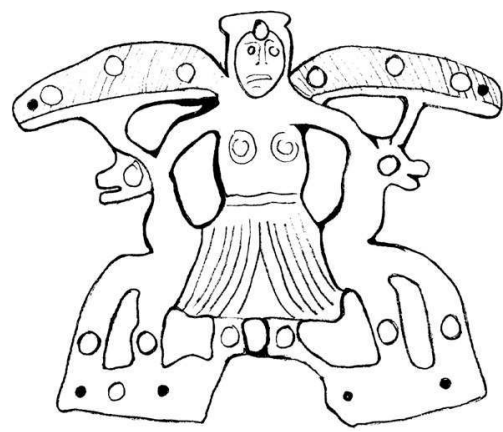

Fig. 10. Golden plaque from Alexandropol tumulus, III B.C. St. Petersburg, Hermitage. (SK, 211) (del. Ekaterina Reshetnikova). 